\title{
Sciendo
}

\section{Making the World Safe for Patriarchy: Trump and the Zombie Apocalypse}

\author{
CHARLES W. NUCKOLLS
}

Department of Anthropology, Brigham Young University, USA

charles_nuckolls@byu.edu

\begin{abstract}
Both Donald Trump in the White House and zombies in American fiction, movie, and television serials, highlight changes in American social structures, especially marriage and childbirth. Instead of a critique of such structures, however, the zombie genre largely reinforces traditional norms. To be sure, Trump himself is not a zombie, although his followers are often represented the living dead in American political cartoons. What is the connection between the two? In the first place, zombie fiction can be viewed as culturally conservative in orientation, because of its emphasis (whether intentionally or not) on the traditional nuclear family. Second, zombies, almost by definition, do not have a leader, except that the genre deliberately toys with this theme in one recent television series. This paper discusses the two themes - crowds that become like zombies and leaders who create zombie-like followers - in the context of the genre's overall conservative critique.
\end{abstract}

KEY WORDS: Donald Trump, marriage and childbirth, violence and sacrifice, zombies 
And what of the dead had not speech for, when living,

They can tell you, being dead: the communication Of the dead is tongued with fire beyond the language of the living. (T.S. Eliot, "Little Gidding")

\section{Introduction}

The focus of this paper is on two American television series, The Walking Dead (2010present) and Z Nation (2014-2018). Both function as conservative cultural critiques, the purpose of which is two-fold: First, to restore the traditional patriarchal family to prominence, and, second, to assert that a nation of patriarchal families should be led by a narcissistic autocrat, prefiguring the rise of Donald Trump.

This is contrary to the popular assumption that the world of the zombie apocalypse is synonymous with the collapse of traditional social structures and systems of meaning. Here the contrary hypothesis is advanced. The traditional patriarchal family is restored and a form of dictatorship created. A ritual of sacrifice serves to re-affirm traditional institutions and to reconstruct the post-apocalyptic world. The Walking Dead, for example, is a form of cultural revanchism masquerading as a fantasy of world annhilation. Z Nation, on the other hand, takes up the theme of leadership and the social replacement of the citizen pubic with a conception of "the crowd" and its deranged and autocratic leader.

The return to "traditional" values is the leitmotif that underpins much of the zombie genre, especially in its American versions. It should come as not surprise that the question of how to exert leadership over such a movement figures prominently in the genre. The Walking Dead considers this question, even though it prefers to concentrate on the theme of blind obedience to an instinct or urge. We are drawn into a world in which social action is not mediated by thought, and in which conscious intentions can be dispensed with. The Walking Dead creates survivor communities in which family values figure prominently, but that is only possible against the backdrop of zombie behavior that knows neither purpose nor aim. But the real question centers on the issue of leadership, since a leaderless society, no matter how regimented, cannot serve as model for the conservative reconstruction of social relations. A hybrid persona is therefore required - someone who is both automaton himself and a leader of automatons, and who thereby points the way to post-apocalyptic social transformation. Donald Trump functions in precisely this role. The role is reflected in the character of "Murphy" in Z Nation - a half-human, half-zombie hybrid who communicates with zombies 
via telepathy and wants nothing more than to create a whole world of zombie hybrids he controls and directs.

\section{Zombies and Classical Crowd Psychology}

The Zombie arrival is usually heralded by epidemic disease that kills the majority of the population, and leaves the rest either as zombies or their human prey. I am Legend, 28 days later, 28 Months Later, and of course The Walking Dead and Z Nation - these and many more constitute only the best known and most recent representatives of the usual plot development (McGINN 1995). Where does the notion come from, that the earth must be depopulated in order to make way for the new world to come? The Book of Revelations is the locus classicus:

And I saw a new heaven and a new earth: for the first heaven and the first earth were passed away; and there was no more sea $(21: 1)$.

And I John saw the holy city, a new Jerusalem, coming down from God out of heaven, prepared as a bride for her husband (21:2).

And God shall wipe away all tears from their eyes; and there shall be no more death, neither sorrow, nor crying, neither shall there be any more pain; for the former things are passed away (21:4).

After the destruction, only a few will remain to witness the coming of God upon his Throne. There will be no people who are "fearful, and unbelieving, and the abominable, and murderers, and whoremongers, and sorcerers, and idolaters, and all liars" (21:8). The world will be nearly empty. Then God shall then "make all things new" (21:5).

However, the annihilation described in Revelations is not the only model of transformation available. Another model exists: The French Revolution. Arguably, no event looms larger in the Western historical imagination unless it is the Fall of Rome, and both produced new social orders from bloodshed and horror. Given that word "apocalypse" itself means a tearing away of the veil, and thus a revelation of what is true and eternal, the religious resonances of the genre trademark "zombie apocalypse" should not surprise us. Like Revelations, the tumultuous end of the Ancien Regime and long before that, the barbarian overthrow of Rome itself, were both seen as world-historical events that marked sudden ruptures of the old. The Paris insurrection in 1789 was unforeseen, but once begun, it consumed the nation like a conflagration. It ended only when autocracy was restored, first by Napoleon, and then 
resumed, on and off, from 1815 through the Bourbon Restoration, by Louis Philippe, and finally by the Second Empire of Napoleon III that culminated in the ignominious defeat by Prussia in 1871.

Gustave Le Bon had small regard for the republican sentiments, and from his vantage point, a century after the French Revolution, he condemned the entire period as exemplary of crowd rule. Le Bon thought that Rousseau was to blame: The philosopher represented the best and the worst of the Age of Reason, on the one hand speaking grandly of mankind's nobility and on the other of the need for the violent overturning of the established order (LE BON 1980). Lesser men are inclined predominantly to revolutionary revolt, claimed Le Bon, and thus inevitably end up producing the disasters to which every revolution is subject. Le Bon believed that the crowd is always to be feared. Like Edmund Burke, he subscribed to the view that only a constitutional monarchy, guided by established tradition, could save modern nations from destructive revolutionary excitements.

Le Bon crystalizes in a single concept, "the crowd," everything that organized societies in the West should abjure. There is something just as bad the crowd, however: "... something very like a dictatorship" (LE BON 1980:73). But can the term "dictator" apply to any of the stock figures that inhabit the zombie genre? A zombie dictator, after all, is a contradiction in terms, for to be a zombie in the first place means to lack the very qualities that would make leadership possible. As an unthinking crowd, and lacking conscious intention, zombies can only do so much. They are prone to drowning, or falling off cliffs, or simply having their legs cut out from under them - literally. From The Walking Dead we learn that the only sensate capacities they retain is the ability to smell and hear, and these capacities lead them to the uninfected humans they will kill and consume.

Yet to interpret the zombie against the theoretical background Le Bon supplies yields interesting results. Let us consider the history of crowd psychology. Published in 1895, Le Bon's The Psychology of Crowds captured the temper of the times. With the growing density of urban life, rapid industrialization, the universal male suffrage, and the rise of the labor movement, observers turned their attention to la foule, "the crowd." Trained as a medical doctor, Le Bon discovered what he claimed were the sources of crowd psychology: The millions of Europeans who, churned up and spat out by the great movements of the day, had been ripped from their rural traditions and values. Drawn to cities, they became the stuff of la foule: A mass shaped by simple ideas, ones that conjured the specter of global conspiracies (usually involving Jews), the sway of an economic elite and the prospect of unlimited immigration from non-Anglo-Saxon nations. These ideas, he observed, circulate inside 
crowds just as microbes do inside a human body, infecting all within their reach. Against this new strain of microbes, the tools of logical analysis offer the weakest of protections.

The consequences, said Le Bon, could be catastrophic. If not quite the walking dead, the infected individuals in Le Bon's schema are reduced to the status of beasts. "By the mere fact that he forms part of an organized crowd, a man descends several rungs in the ladder of civilization. Isolated, he may be a cultivated individual; in a crowd, he is a barbarian - that is, a creature acting by instinct" (LE BON 2002:83). Unlike the freelancing zombies in television drama $Z$ Nation, however, these particular creatures require a leader, a charismatic figure who, adept in the art of public relations, seeks simple ends: To win power for the sake of power - or, rather, to maintain an elite of winners over the mass of losers.

Le Bon observed that crowd members are consumed by a near-religious fervor. As with the fiercest religious sect, so too with the modern crowd: Its commonly held convictions "assume the characteristics of blind submission, fierce intolerance, and the need of violent propaganda." The crowd's leader is "acclaimed as a veritable god," holding sway over its imagination by "devising new formulas as devoid as possible of precise meaning," thus taking on whatever meaning the follower invents. At the same time, the leader destroys his rivals with claims devoid of substance: "By dint of affirmation, repetition, and contagion" the crowd's leader affirms that his opponent is "an errant scoundrel, and that it is a matter of common knowledge that he has been guilty of several crimes." Almost as an afterthought, Le Bon concludes: "It is, of course, useless to trouble about any semblance of proof" (LE BON 2002:79).

To his bourgeois readership, Le Bon offered a diagnosis of the troubled state of France's contemporary social health. France had been wracked by a series of crises, beginning with the collapse of the major banks and stock market in 1882, stretching through the rise of nationalist, anti-Semitic, and anti-republican movements, like the Boulanger Affair of the late 1880s. This was followed by political conflagrations such as the "Panama scandals" of 1892 and a rash of anarchist bombings and assassinations through the early 1890s, all of which were eclipsed by the Dreyfus Affair. The present age certainly appeared, as Le Bon declared, to belong to the crowd.

The "crowd" is the perfect template for the zombie hordes that invade the public psyche in the early $21^{\text {st }}$ century. That should not surprise us. Le Bon was reacting against the unprecedented crowd dynamics that temporarily abolished the French monarchy and permanently put an end to rule by aristocrats. But Le Bon went further, and wrote his next most famous book on the insanity of the European mobs in the days leading up to the First World War. If Le Bon did not address public media, it was because the discipline he created 
- crowd psychology - had not yet matured. This job fell to Edward Bernays, Freud's nephew, and the author Public Relations (1945), and of the still popular Crystalizing Public Opinion (1923) and Propaganda (1928). It was Bernays who convinced women to take up smoking - then considered unladylike - by linking cigarettes to female emancipation, calling them "torches of freedom."

Just why the public's imagination turned to animated corpses at the end of the last century is beyond the scope of this chapter (see HALBERSTAM 2020; LAURO 2017; LEVINA - BUI 2013; SCOTT 2020). There was no stopping the steady proliferation of zombie books, comics, movies, and television shows. The public was (and remains) insatiable, much like the biting and chewing creatures that fascinate them. Along the way, questions of zombie physiology and brain function have been considered, including the question of whether or not the undead retain dim memories of their existence prior to "turning." A small number of television shows considered this possibility, and expanded on it, e.g., the British In the Flesh (2013-2014); the French The Returned [Les Revenants] (2012-2015); the Australian Glitch (2015-2019); and the American Resurrection (2014-2015). Apart from these (mostly) foreign serials, the American versions have all steered clear of exploring memory and the continuity of self. The premier zombie series, The Walking Dead, is a case in point. The series devoted a couple of early episodes to an experiment designed to imprint on the mind of an old man dying of cancer certain spoken words and phrases of music. Once "dead," would his zombie self, returned to life, exhibit recognition when prompted by cues? Interestingly, the audience never finds out, since one of the series' principle characters ("Angela") reacts to the suddenly energetic old zombie by putting a knife through his head. Surely the reason is obvious. The implications of making zombies even dimly self-aware would suggest the possibility of cure. It would almost certainly reduce (or cast doubt on) the wanton violence with which they are dispatched by living humans. As we shall see, violence is essential to sacrifice, the sacrifice through which the survivor group reconstitutes itself on the basis of traditional and patriarchal institutions.

Despite its ten-year run, The Walking Dead never once returned to this question, preferring to cast the dead in their non-cerebral role as forever unsatisfied consumers of flesh. Steven Zani and Kevin Meaux contend that this renders them a "blank template" (ZANI - MEAUX 2011:99) onto which we graft all sorts of American anxieties, including the fear of rising rates of senile dementia, especially among aging Baby Boomers. Still, the issue of consciousness cannot be escaped, since transforming the undead into a crowd that can be led (and thus manipulated) by an autocrat remains crucial to their deployment as a trope for the right-wing Republican movement under Trump. The problem is addressed, however, in 
another television series, Z Nation, almost unique in the genre, not just for its mordent sense of humor, but for inventing the figure of the zombie manqué.

\section{Leading the Unthinking Crowd}

Z Nation begins several years a virus has killed most humans. In the days before the unexplained catastrophe, the character known as "Murphy" was an inmate at a naval hospital who became the unwilling subject in a government-sponsored experiment on a possible vaccine. Murphy was the only subject to survive the injection. Then he was exposed to zombies, who proceeded to bite and attack him. He survived, his body covered with bitemark scars. Scientists concluded that his blood contains antibodies that are the last and best hope for a vaccine. But the facility was overrun before further tests could be done.

Shortly after, Murphy begins to mutate into some form of hybrid between zombie and human. His skin sheds and his body turns blue, and he seems to be able to control and even hypnotize the zombies he encounters. Murphy discovers that his saliva renders ordinary humans immune to zombie bites, but makes them susceptible to mind control. Until then, the survivor group only knows of Murphy's importance to the development of a vaccine, and they try to escort him to government laboratory in California. Murphy, however, makes this difficult, since in addition to being half-human, he exhibits strong tendencies to narcissism and greed. When he rejoins the group after each selfish jaunt, he is sheepish and contrite, but only briefly. Invariably he embarks on another mad escapade, seeking gratification on his own terms. Yet he has not turned into a full zombie and still remains in control of himself. There are many twists and turns in the plot over the five years of Z Nation, and along the way Murphy falls in love with a mysterious woman (later killed) and conceives a child, whom he leaves under the protection of a farmer couple whom he converts into hybrid zombies. Later we will see why matrimony and childbirth are foregrounded, again and again, in American zombie fiction. What stands out is the acknowledgment that zombies possess minds, and these minds can be manipulated by a man who is one of them, but whose skin color (among other things) marks him as different. Will he use this power for good, to help the survivor group dedicated to saving him, or will turn even more into a zombie narcissist?

The fact that Trump supporters are sometimes represented in public media caricatures as mindless clones, without intelligence or conscious awareness, comes as no surprise. Political opponents usually represent each other as witless dupes. Opponents found Trump's weird mind control over his adoring legions incomprehensible. His cinematic counterpart is the 
half-zombie Murphy. Trump's legions were the same people who heard him declare that he could "stand in the middle of Fifth Avenue and shoot someone and I wouldn't lose any voters" and cheered him on. Many said they would die for him, and that turned out to be no exaggeration. Newspapers in early 2021 reported on a nurse, somewhere in the northern Midwest, who tearfully explained that she had offered to set up a telephone call between a patient on the brink of dying from Covid-19 and members of his family. The patient refused, because, he said "I don't have Covid; Trump said it was only the flu." This is reminiscent of the 2017 zombie horror film Bushwick. The film begins like a lot of zombie flicks. An unsuspecting couple is walking through a subway station in the working-class neighborhood of Bushwick in Brooklyn. The station is eerily empty. They hear gunfire outside. The boyfriend goes out to investigate, and the audience knows from the conventions of zombie films that this is a bad idea. No need for a spoiler alert: He dies. The girlfriend ventures out to find the residents of Bushwick fighting an invading horde. But it is not a horde of zombies, even though they are committed to the same relentless violence. The invasion force turns out to be a right-wing paramilitary bent on securing the secession of Texas and most of the South from the United States.

The usefulness of the zombie trope explains its power of endurance. They fall into the category George Lakoff calls "pathological stereotypes" (LAKOFF 2016). It might seem that this would prove serviceable only on the political left. After all, to call somebody "zombielike" is hardly a compliment. This is not the whole picture, however. From audience surveys, we know that the genre is just as popular on the political right as it is on the left. There must be aspects of zombie-hood that conservative extremists not only admire, but actually seek to emulate. What are these aspects? Just before the 2020 election I interviewed several members of this community, to get their take on the zombie genre. All agreed zombie films were great fun. Then one man - a white man in his 40's - said, "and you know what, I like zombies because zombies get things done." He was joking, but there was a hint of gleeful admiration in his remarks.

The logic behind this observation is found in the unswerving power of mindless zombies to accomplish the one thing that is their special talent: Total destruction. Zombies do not exist without destroying the world and forcing the survivors to rebuild it. Years ago Americans heard the advisor to President George W. Bush, Grover Norquist, say that the goal of the Republican Party was "to shrink the government down to the size you could drown it in a bathtub." Trump became popular because of his promise to uproot and destroy the established order, even if it meant casualties. The old order must be obliterated in paroxysms of violence that Trump and his followers explicitly endorsed, especially in the period leading up to the January 6, 2021, capitol insurrection. It is small wonder, then, that Trump's supporters 
identify with the zombie mission to destroy and remake the earth. Only one element is missing - a Murphy-like character who is not as crazed as the people he manipulates, who is a liar, and who acts out narcissistic fantasies of domination and control. That role, of course, has been assumed by Donald Trump himself. There is even a resemblance in skin color: The greater Murphy's power to control zombies become, the more extreme the color of his skin. Many have noted the same thing in Trump: He begins as a man whose skins appeared soft and pasty white in the early years to one whose skin now shines with brilliant orange luminescence. Murphy is blue, but apart from that, the two are surprisingly similar.

To say that Trumpism owes some of its symbolic power from the zombie apocalypse is to say that the latter functions as model for concerted action. It is not that most people, conservative or otherwise, want to die and come back to life as unthinking automatons. Yet the immersing of oneself in a group possesses a certain appeal, a fact recognized repeatedly, from Gustave Le Bon to Hannah Arendt. The same theme is developed in anthropological studies of religious movements that pass through periods of doctrinal conformity and periods of ecstasy (see WHITEHOUSE 2004.) We are forced to conclude that the undead as a trope for political action functions as more than a metaphor of disparagement in the liberal rhetorical tool-box. Zombies are also a model for the group whose purpose is established by the fanatical leader - one who is able to translate his own narcissistic fantasy into group political action (COLLINS - BOND 2011).

\section{Trump, Zombies, and the Conservative Cultural Critique}

The Trump movement, however, depends on zombies for more than this, since it prepares the world not only for destruction but also for replacement by something the movement considers better. Zombie shows put into play that most ancient of conservative shibboleths, the nuclear family. Zombies, in fact, serve as a conservative cultural critique of everything conservative America believes is wrong with the modern family: divorce, feminism, delayed or absent childbirth, etc. To restore the family to its supposed ideal requires a world made anew, one which the zombies create by attacking (and then eating) the opposition. Now enters a theme that is basic to the Christian worldview: the importance of sacrifice. Let us recall that in zombie fiction personal vengeance is almost completely absent. In the first episode of The Walking Dead, when a man tries (but fails) to shoot his zombie-wife, she eventually ends up biting and killing their son, and the husband goes insane. This is intended to suggest the moral dilemma in killing someone who is known and loved, and (more importantly) to foreshadow the child sacrifice that later serves as means for reconstructing social solidarity on the basis 
of reproductively fertile marriage. But for the most part "walkers" (the term used in the series for zombies) are not known to the people who stab them, run over them, or decapitate them. This is critica to their function in performing sacrifice. In this respect they resemble the victims of vicarious violence in tribal societies. But victims of violence in this sense must stand in for a group if the violence against them is to be considered a vicarious sacrifice. Do zombies qualify?

Clearly, zombies do not stand in for groups of other zombies. Killing them is no different from killing any other dangerous predatory creature. But the fact that zombie-killing goes beyond mechanical expediency or the need for self-preservation is absolutely striking. A zombie that is stabbed fifty times, and is already "dead," does not have to be stabbed fifty more times in order to get the job done. And yet violence of this magnitude is commonplace in The Walking Dead. The "extra" violence, as it were, could be the direct result of the fact that zombies function as sacrifices, and stand in for someone else - possibly the survivor group itself, now that it is riven by internal dissension. The group requires the sacrifice of innocents in order to restore internal harmony.

In his studies of ritual sacrifice, René Girard showed that victims of group violence often function as "scapegoats" (GIRARD 1976, 2007). A society previously held together by structures of differentiation and mechanisms of retaliation finds its viability threatened by escalating vengeance of all against all, often aggravated by famine, pestilence, military threat, or disorder. Does this not resemble the United States today in all its partisan rancor? In order to mitigate internal tensions and the threat of intra-group violence, a group will select - or someone actually volunteer - to serve as a receptacle for the group's own pent-up hatred. The victim is then sacrificed with ceremonial violence. Something about the scapegoat's marginality makes the execution appear fair to the perpetrators. The scapegoat is then seen as noble sacrifice, even a savior figure, since the violence against him or her ends the spiral of internal violence and brings peace. Then the group returns to homeostatic balance - at least for a while.

Not all zombies serve equally well for this purpose. Random zombies converted from ordinary adults - usually because they have been bitten by other zombies - function only as a mundane mechanism of sacrifice. Killing them with wanton violence confirms the social solidarity of the survivor group, and that's fine, as far as it goes. But best sort of victims, the ones whose violent extermination best serve the solidarity-reinforcing function of sacrifice, must (if the Girardian hypothesis is correct) be defined as innocent even through their status as zombies makes killing them necessary. Here one recalls the child "Sophia" in the second season of The Walking Dead. Sophia is a little girl who wanders off and is later discovered 
in a barn full of zombies who must all be shot, assembly-line fashion, as they emerge from inside. She is now a zombie, but visually bears only a few marks of her transformation. Sophia is still more childlike in appearance than zombie, thus making her the ideal sacrifice on behalf of the group. She is still, partly at least, a member of the survivor group, and as her mother looks on, we see the group respond to her presence both with dread and loving recognition. An innocent victim always makes the best sacrifice. The shot is fired by the leader of the group, a former sheriff, and this serves two functions. First, the sheriff acts in the role high priest to perform the group's most perfect sacrifice, its own child. Second, the killing serves to solidify the group, which had, up this point, been on the verge of disintegration through internal competition. The group now shares participation in a sacrificial killing - they are all to blame - and the internal divisions diminish in due proportion.

Does the conservative critique offered by Trump depend on the sacrifice of victims? During the 2016 election season a Trump rally that did not involve violence against someone was a rare thing. For the most part, the victims were identified as "liberals" and "lefties," and beating them up made the Trump audience experience a sense of self-righteous victory. On the other hand, the victims were still classified as Americans, and thus, in an ordinary sense, doing them harm might violate the group's ethical norms. But that is not the issue. Americans innocent of everything except speaking their own minds must be assaulted and removed for the good of the nation, and for Trump, the leader. In other words, it is a sacrifice that had to be made, and making it excuses participants of moral responsibility. The effect was to identify opponents and weaken them, but also, more importantly, to show that group members were willing to commit heinous acts of violence even against members of their own society. This is the logic of sacrifice.

Violence that goes beyond merely exterminating zombies affirms the solidarity of the group by stressing their difference from the beings they kill, and also by confirming them members of the same group. But communal vengeance is not necessarily sufficient to create the cohesiveness the group requires, especially when that quality is constantly put at risk by the selfish designs of individual group members. Vengeance is not enough in a drama as thoroughly steeped in Christian values as the average television zombie show. The Walking Dead requires stronger sacramental medicine.

To be rendered complete, violence must transform itself into the sacrifice of innocence. More than that, the sacrificial victim must resemble the people who are scarifying her. "The true distinction," as Girard puts it, "between the sacrificeble and the non-sacrificeble is never clearly articulated" (GIRARD 1996:83). That is why Sophia is not hacked or bludgeoned, 
but shot cleanly with a bullet to the head. She is "like us" and her execution must take place with a minimum of violence. Sophia's killing marks the transcendence of vengeance through the redemptive logic of sacrifice and into a sacramental rite that can restore the institution of marriage, and with it, the conservative image of the good society.

How do we know that the sacrifice of innocence serves the purpose Girard said it should that is, to prop up the social solidarity of a group whose internal tensions threaten to destroy it? Consider the social dynamics of the zombie survivor group in The Walking Dead. Up to this point the group has lost members and its leader, the sheriff, has barely withstood a powerful challenge to his authority. They have lost their place of refuge - a farmhouse - after it is overrun by a "herd" of walkers. The survival of the group is in doubt. Killing more zombies will not exorcize the demons that haunt the group and threaten it with disintegration. Something else is needed, and the solution is in keeping with the traditional Christian view of sacrifice. Recall the moment, not long before Sophia is killed, when the sheriff finds himself in an abandoned Christian church. He and his fellow searchers are drawn to the church because somehow the church bell is still ringing every hour (they later discover it is on an automatic timer). They do not find Sophia - she has already been bitten and turned into a zombie - but they do find a large crucifix, and Rick prays to the image of Christ. This is the only time in the first four seasons of the television series we observe a major character involved in an act of Christian prayer. The fact that Christ has been revealed in this episode, and as part of a request to redeem childhood innocence (in the character of Sophia,) suggests that the two are related symbolically. In other words, the young girl and Christ are perfectly innocent, and their sacrifice means more than simply a restoration of group solidarity. Indeed, that is the whole point: vengeance as a cure for declining social solidarity can only take the group so far before the powerful logic of Christian redemptive sacrifice - the sacrifice of the perfect innocent - is required to fully redeem the solidarity of the group. Killing, but not vengeful killing, does the job, and it is the logic of Christian sacrifice that serves as the model.

\section{Zombies and Restoration of Marriage: How Zombies Remake Society According to the Conservative Model}

In The Walking Dead, forgiveness between husband and wife turns out to critical to the restoration of marriage as an institution. Trump himself, oddly, was seen by the Christian right as the savior of traditional institutions. In fact, marital reconciliation - in its most traditional form - is a fundamental objective of the zombie genre and of conservative politics in general. This might seem surprising. Despite decades of critique and the decline of 
matrimony as a social practice, the conservative Christian ideal of marriage persists. The Walking Dead presents the case for its restoration. But how can zombies perform this function? Zombies themselves are notably devoid of matrimonial features or sexual inclinations. In their standard cinematic form, zombies cannot kill or be killed without extreme violence. To kill, a zombie must bite, although whether or not it can orally ingest its victim is unclear; some zombies do not possess any body parts or appendages below the level of the neck. Even when zombies are still in possession of whole bodies - with the ability to walk, run, and use their hands - they remain incapable of sexual violence. There is no such thing as a male zombie with an erection, or, apparently, a zombie who can commit rape. Nor do we find female zombies described as victims of sexual assault. Whatever else zombies may do, or have done to them, sexual crimes are notable by their absence.

In The Walking Dead, a small group of people led by a former sheriff make their way out of Atlanta and through the Georgia countryside, trying to escape the walkers. The political organization of the group is interesting. It begins as an ostensibly democratic body with decisions reached through consensus. As it gets smaller - there are many deaths through zombie depredation and attacks by other human beings - the democratic forms wither until finally the sheriff declares (with his face aglow from a campfire) that the group is no longer a democracy, but a patriarchy led by one man (i.e., the sheriff). The series suggests that reduced to its essence, a kind of primitive patriarchy, society can and should be rebuilt. The zombies themselves have made the world safe for patriarchy. Not surprisingly, the same thing is said, in all but name, about American democracy under Trump. But how is this to be brought about?

Earlier, the sheriff and his wife, Laurie, had been separated at the beginning of the apocalypse. When he finds her, she is already with a group that includes the sheriff's deputy. Rick (the sheriff) does not know that Laurie and deputy have been sexually involved with each other, and it comes as a surprise to both when Rick turns up having survived the zombiepacked streets. The deputy is not pleased, and over the course of several episodes gradually hatches a plot to eliminate his rival. But Rick kills him first - and then kills him again when he (the deputy) turns into a zombie. All seems right with the world. And yet we find a troubling disquiet in the relationship between Rick and Laurie. He cannot forgive her for her sexual indiscretion, even though it was committed in ignorance of his own survival. She cannot forgive him for killing her former lover, and for not forgiving her. Their marriage formally redeemed, the two are more estranged than ever, and this (the series suggests) puts at risk the restoration of society in the post-apocalyptic world. The fact that Laurie is pregnant (with whose child is never clear) provides scope for marital repair. 
Marital redemption, it turns out, is a function the zombies perform, on behalf of the American conservative movement that identifies itself with traditional institutions. Zombies make forgiveness possible by enabling husband and wife to restore marital sexuality and its approved product, childbirth, to their traditional positions as core constituents of American social structure. Rick and Laurie are forced, slowly but surely, to recognize their marital relationship as central to the survival of the group. They are, after all, the sole married couple in the survivor group at this point in the development of the plot. And for a social structure defined by marital sexuality to be restored, Rick and Laurie must prove that marriage works. There is no way to do that in the American cultural scheme of things without the birth of a child. This is consonant with the Trump Republican rejection of abortion. Does Trump himself really care? It makes no difference. His political movement is inconceivable without an anti-abortion stance. The reigning zombie motif on American television serves only to strengthen this motif.

The contrast to productive marital sexuality is the zombie. Zombies are perverse because they privilege the alimentary over the sexual, and thus subvert the primary symbolic importance of martial sexuality and childbirth. Pregnancy and birth are not alimentary processes. They stand in opposition to a zombie morality that defines action solely through consumption that is, through proper or improper ingestion. But that is not to say that the two symbols are always clearly opposed. Sometimes, it is by deliberately juxtaposing radically divergent symbols that the preferred or dominant symbol receives motivating power. Pregnancy/birth is a case in point. As an extension of the primary symbol of marital sexuality, childbirth must be maintained as a distinct point of meaning, in order to preserve marriage as the fundamental building block of the social order. But The Walking Dead makes this essentially Victorian point by setting it side by side with something that looks like the product of virtuous sexuality but is something else.

A full belly is not easily distinguished by appearance alone from pregnancy. In fact, for a long time the two were considered related - as in the belief, still current in parts of the United States, that a woman may become pregnant by eating certain things. The Walking Dead makes the contrast explicit. After Laurie is dead, her half-deranged husband encounters a zombie with a peculiarly distended belly in near proximity to the place where his wife died. This is the first fat zombie we have seen. Rick repeatedly stabs the monster, not in the head, where it can do the most good, but in the stomach. Does he believe the zombie has glutted himself on his wife's remains? The episode fails to make this clear. The point seems to be that the full stomach of the zombie represents improper ingestion - a kind of false image of pregnancy. Laurie's distended belly represents the triumph of marital sexuality - a triumph of the gestational over the alimentary, of correct reproduction over evil consumption. It is 
true that we do not know for sure if the sheriff, Laurie's husband, is the biological father. But the film makes it clear that socially the child will be considered his, and this is all that is necessary to confirm the overriding importance of marriage as the fundamental constituent of the good society.

The process is not complete, however, until husband and wife are restored in forgiveness of each other. This is what the conservative agenda requires. Forgiveness is represented as a thoughtful (almost mystical) coming to terms of Rick with his own guilt at having failed at reconciliation while his wife was still alive. The issue is complex because there remains the troubling possibility that Laurie was impregnated by her lover (the deputy), and not by her husband (the sheriff). But Laurie dies in childbirth. Her death "solves" the problem and, paradoxically, restores the sanctity of marriage. Rick eventually comes to terms with his failure earlier to accept his wife, no matter what, and regardless of who the actual father of her baby is. Laurie herself is now utterly ethereal and without corporeal passions. She appears to Rick as a disembodied voice over a dead phone line and as a ghost who finally extends her hand and gently caresses Rick's cheek. Two things make martial redemption possible. One is the birth of the child, a daughter, who stands in for Laurie and forces Rick to choose life over death and guilt. The other is Laurie's ghostly existence as a phantom produced by Rick's own guilty conscience. The reproductive power of marriage to restore society is maintained, and the survivor community (although much diminished and under threat) can continue. Even in Z Nation, the half-zombie Murphy, manages to impregnate a normal woman and produce a child, thus partially redeeming himself and setting the stage for leadership of the zombie "community." Morality is thus established by defining what should go into and what should come out of the body.

In The Walking Dead, a woman leads the way by asserting, through pregnancy and childbirth, that marital fertility wins out over simple consumption. But it is left to the husband to complete the process, by forgiving himself and his wife, and by doing so reclaiming the superior status of martial reproduction over individual consumption as a foundation for society. Only the man can accomplish this, strengthening the sense in which the conservative zombie apocalypse must result in the return of patriarchy (KUMAR 1995).

The Walking Dead is fundamentally a commentary on key social structures, presented in surprisingly traditional forms, and at a time when the conservative movement under Trump was gaining strength. This fact is critical to our understanding of the moral economy of zombies. From David Schneider we know that sexual intercourse is the paramount symbol of the marital relationship in American culture (SCHNEIDER 1980). The fact that this symbol remains a fixed point of reference in the post-apocalyptic world suggests that 
monogamous marriage itself transcends the apocalypse, just as Trump, we are told, transcends the importance of party. A key purpose of the Trumpian apocalypse is to restore marriage and the power of marital reproduction to serve as a principle identifying symbol for the Trumpian social order. In zombie films, interestingly, we find remarkably little experimentation with alternative relationship structures, like polyandry or group marriage. The ideal of monogamous marriage remains remarkably intact, even in the case of the thricemarried Trump, and one that the struggle for survival only serves to intensify.

But, again, we come back to the question: Why zombies, or rather, why do they serve so effectively as the background against which to reconstruct the conservative movement's ideal of "traditional" marriage? The zombie apocalypse is useful because of it pits the overwhelming atavism of the zombies against the formation and maintenance of marriage, the primary traditional bond in American kinship. The symbol of selfish atavism is individual consumption, and zombie fiction reduces consumption to its fundamental essence: Eating. The threat is that of alimentary individualism, a thing that zombies typify, since they are perfect consuming machines and nothing else. Only living humans can get married. It seems like a simple enough point, but think what a difference it would make if zombies were shown acting in pairs? It would be funny - a fact not loss on the makers of zombie spoof films (e.g., Warm Bodies) which deliberately undo the usual horrors of the undead by linking the life after death the search for romantic happiness. And then there is the more recent social phenomenon in the United States of "zombie theme weddings" - but this subject, however fascinating, would take us too far afield.

\section{Conclusion}

The Trumpian movement, as understood by its adherents, proclaims that current problems can be solved by a return to traditional social structures and practices. The "problem" presented in the American television series, The Walking Dead, is that zombies have nearly ended human society. But the problem is also the solution. Destruction must precede the struggle to rebuild (BALAJI 2013). The people who are left must somehow cope, and do so, slowly and with setbacks, by attempting to reconstruct the society that unrestrained individualist consumption has almost destroyed. Trump, of course, promised to do the same, and in way, he led the way (almost) to his own apocalypse with the attempted coup. Sacrifice and kinship are basic to this process. The first functions to relieve the survivor community of its divisive internal tensions by choosing a sacrifice - a young girl whose obvious innocence makes her the perfect substitute for the group itself. In killing her, they do, in a sense, mortify 
themselves, but the sacrifice of her innocence (like that of Christ's) renews the community's sense of purpose. They must now, in the words of one character, live their lives "for her," as her death becomes a monument to their own desire to rebuild society.

A society renewed on the basis of child sacrifice - a form of vicarious violence against itself - can be rebuilt using the kinship structures known to have withstood adversity in other crises, from disease to natural disaster. The post-apocalyptic world - with its strongly Trumpian overtones - seeks to return to the conjugal ideal as the basis for beginning again. The fact that it performs this function is another indication of the television series' implicit cultural conservatism. Of course, to redeem marriage it must be carefully refurbished. This means getting rid of the elements that in American society are usually thought most inimical to marriage: selfishness and its correlate, infidelity. The Walking Dead fixes all this, and resurrects marriage by grounding it in the fundamental importance of reproduction. Is it ironic that a president with a history of extramarital affairs leads the conservative movement to restore "traditional value?" Perhaps. But it is surely significant that the only child born in the first two seasons of the television show is the child of a couple whose marriage has been nearly destroyed and then redeemed through the mystical powers of matrimony - powers, the show suggests, that transcend even death. Trump is also redeemed by means of same process - marriage to a loyal and faithful (albeit foreign) woman, and the birth of a son. Whether or not he ends up leading people into the redemption of the post-apocalyptic world remains to be seen. It might depend on whether or not the apocalypse, in American political terms, has already happened - or is yet to come.

\section{Bibliography}

BALAJI, Murali (ed.) (2013): Thinking Dead: What the Zombie Apocalypse Means. New York: Lexington.

BERNAYS, Edward (2011 [1923]): Crystalizing Public Opinion. New York: IG Publishing.

BERNAYS, Edward (1928): Propaganda. New York: Horace Liveright.

BERNAYS, Edward (1945): Public Relations. Boston: Bellman.

COLLINS, Margo - BOND, Elson (2011): 'Off the Page and into Your Brains:' New Millennium Zombie and the Scourge of Hopeful Apocalypses. In Deborah Christie, Sarah 
Juliet Lauro (eds.): Better Off Dead: The Evolution of the Zombie as Post-Human. New York: Fordham, pp. 187-204.

GIRARD, René (1996): Sacrifice as Sacral Violence and Substitution. In James Williams (ed.): The Rene Girard Reader. New York: Crossroad, pp. 66-97.

GIRARD, René (2007): Evolution and Conversion: Dialogues on the Origins of Culture. London: T\& T Clark.

HALBERSTAM, Jack (2020): Wild Things: The Disorder of Desire. Durham: Duke University Press.

KUMAR, Krishan (1995): Apocalypse, Millennium, and Utopia Today. In Malcolm Bull (ed.): Apocalypse Theory and the Ends of the World. Oxford: Blackwell, pp. 200-226.

LAKOFF, George (2016): Moral Politics: How Liberals and Conservatives Think. Chicago: University of Chicago Press.

LAURO, Sarah Juliet (ed.) (2017): Zombie Theory: A Reader. Minneapolis: University of Minnesota Press.

LE BON, Gustave (1980): The French Revolution and the Psychology of Revolution. New Brunswick: Transaction.

LE BON, Gustave (2002): The Crowd: A Study of the Popular Mind. Mineola: Dover Publications.

LEVINA, Marina - BUI, Diem-My (eds.) (2013): Monster Culture: A Reader. London: Bloomsburg.

McGINN, Bernard (1995). The End of the World and the Beginning of Christendom. In Malcolm Bull (ed.): Apocalypse Theory and the Ends of the World. Oxford: Blackwell, pp. 58-89.

SCHNEIDER, David (1980): American Kinship: A Cultural Account. $2^{\text {nd }}$ edition. Chicago: University of Chicago Press.

SCOTT, Paul (2020): From Contagion to Cogitation: The Evolving Television Zombie. In Science Fiction Studies 47 (1), pp. 93-110.

WHITEHOUSE, Harvey (2004): Modes of Religiosity. New York: AltaMira Press.

ZANI, Steven - MEAUX, Kevin (2011): Lucio Fulci and the Decaying Definition of Zombie Narratives. In Deborah Christie, Sarah Juliet Lauro (eds.): Better Off Dead: The Evolution of the Zombie as Post-Human. New York: Fordham, pp. 98-115. 
Charles W. NUCKOLLS

Making the World Safe for Patriarchy: Trump and the Zombie Apocalypse

\section{Internet Sources}

Z-Nation. Drama/Comedy Series, 2013-2018. https://www.syfy.com/z-nation

Charles W. NUCKOLLS is an anthropologist who works at the interface of cognitive science and psychoanalysis. His books include The Cultural Dialectics of Knowledge and Desire (University of Wisconsin Press), Siblings in South Asia (Guildford Publications), and Culture: $A$ Problem that Cannot be Solved (University of Wisconsin Press). Formerly he was Professor of Anthropology at Emory University and the University of Alabama. He is now Professor and former Chair of Anthropology at Brigham Young University in Provo, Utah.

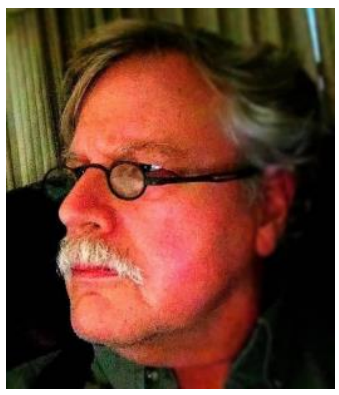

DOI: 10.2478/eas-2021-0009 C) University of SS. Cyril and Methodius in Trnava. All rights reserved. 